\title{
The genera Architipula Handlirsch, 1906 and Grimmenia Krzemiński and Zessin, 1990 (Diptera: Limoniidae) from the Lower Jurassic of England
}

\author{
Katarzyna Kopeć, Wiesław Krzemiński, Karina Skowron, and Robert Coram
}

\begin{abstract}
A new diagnosis and systematic clarification of the genus Architipula Handlirsch, 1906 (Diptera, Limoniidae) are presented. Architipula seebachiana Handlirsch, 1906 and $A$. seebachi (Geinitz, 1884) are synonymised. Liassotipula Tillyard, 1933 from the Lower Jurassic (Toarcian) of England is here considered to be a junior synonym of Architipula. The subgenus Architipula (Grimmenia Krzemiński and Zessin, 1990) is raised to the rank of genus Grimmenia and a new species, Grimmenia tillyardi n. sp., is described from the Toarcian of England.
\end{abstract}

Katarzyna Kopeć. Institute of Systematics and Evolution of Animals, Polish Academy of Sciences, 31-016 Kraków, Poland. k_slazyk@poczta.onet.pl

Wiesław Krzemiński. Institute of Biology, Pedagogical University of Kraków, Podbrzezie 3, 31-054 Kraków, Poland. krzeminski@muzeum.pan.krakow.pl

Karina Skowron. Institute of Biology, Pedagogical University of Kraków, Podbrzezie 3, 31-054 Kraków,

Poland. karina19890@gmail.com

Robert Coram. 6 Battlemead, Swanage, Dorset BH19 1PH, UK. robertcoram@btconnect.com

Keywords: Toarcian; Limoniidae; Liassotipula; Architipula; Grimmenia; new species

Submission: 26 January 2016 Acceptance: 28 March 2017

\section{INTRODUCTION}

Currently, Limoniidae (limoniid crane flies) are one of the largest families of Diptera (true flies), with approximately 11,000 described extant species (Oosterbroek, 2016). The earliest fossils of the family are well represented from the Triassic (Krzemiński, 1992a, 1992b; Shcherbakov et al.,
1995; Krzemiński and Evenhuis, 2000; Krzemiński and Krzemińska, 2003; Blagoderov et al., 2007), and they are particularly abundant in the Jurassic (Handlirsch, 1906, 1939; Bode, 1953; Rohdendorf, 1962; Kalugina and Kovalev, 1985; Krzemiński and Kovalev, 1988; Krzemiński and Zessin, 1990; Krzemiński and Krzemińska, 2003; Lukashevich, 2009; Gao et al., 2015b; Oberprieler et al., 2015).

http://zoobank.org/2CE48DF7-3723-491C-8AA4-80CF972B9EDB

Kopeć, Katarzyna, Krzemiński, Wiesław, Skowron, Karina, and Coram, Robert. 2017. The genera Architipula Handlirsch, 1906 and Grimmenia Krzemiński and Zessin, 1990 (Diptera: Limoniidae) from the Lower Jurassic of England. Palaeontologia Electronica 20.1.15A: 1-7

palaeo-electronica.org/content/2017/1808-diptera-from-england 
Handlirsch $(1906,1939)$ described a number of species from the Lower Jurassic of Dobbertin, Germany, which were classified as a separate family, the Architipulidae. However, Kalugina, 1985 (in Kalugina and Kovalev, 1985) determined that the wing venation of Architipulidae is very similar to that of Limoniidae and assigned them to this family in the rank of a subfamily, Architipulinae. The genus Architipula is the biggest in this subfamily. There are approximately 50 described species, but most of them need to be revised. The oldest representative of the genus is $A$. youngi Krzemiński from the Norian (Upper Triassic) of North America (Krzemiński, 1992a), but the great majority of species derive from the Jurassic Period (Handlirsch, 1906, 1939; Tillyard, 1933; Bode, 1953; Rohdendorf, 1962; Kalugina, 1985 [in Kalugina and Kovalev, 1985]; Krzemiński and Kovalev, 1988; Krzemiński and Zessin, 1990; Krzemiński, 1992a, 1992b; Evenhuis, 1994; Krzemiński and Evenhuis, 2000; Krzemiński and Krzemińska, 2003; Blagoderov et al., 2007; Lukashevich, 2009).

Information about the Limoniidae from the Lower Jurassic of England can be found in Brodie (1845) and Tillyard (1933). Study of their original fossil material and specimens of Architipulinae from the Lower Jurassic of Germany described by Handlirsch (1906) and Krzemiński and Zessin (1990) revealed that the genus Liassotipula Tillyard, 1933 should be synonymised with the genus Architipula Handlirsch, 1906.

This article aims to give an overview of limoniid material from the Toarcian (Lower Jurassic) of England, which comprises eight wings, six of which belong to the genus Architipula, the other two to Grimmenia Krzemiński and Zessin, 1990. Additional Lower Jurassic limoniid material has recently been recovered from older Sinemurian deposits by one of the authors (RAC) and will be described separately.

\section{MATERIAL AND METHODS}

The English Toarcian material was collected in the early nineteenth century by P.B. Brodie and T.J. Slatter from Alderton Hill and Dumbleton, Gloucestershire. It was acquired by the Natural History Museum, London, in 1888 and is housed in the Palaeontological Collection, Department of Earth Sciences. Examined type material from the Toarcian of Germany is housed in the collection ErnstMoritz-Arndt-Universität Greifswald, Germany.

The specimens were studied with the use of a Leica MZF LII stereomicroscope under reflected and transmitted light. Photographs were made with a Leica DFC 295 camera attached to the microscope. Wetting the surfaces with $98 \%$ ethyl alcohol improved image contrast. All line drawings were made from the photographs and digitally processed. Line drawings were prepared with GIMP graphic software (www.gimp.org/). The terminology of wing venation followed Krzemiński and Krzemińska (2003) and Krzemińska et al. (2009).

\section{SYSTEMATIC PALAEONTOLOGY}

Order DIPTERA Linnaeus, 1758

Infraorder TIPULOMORPHA Rohdendorf, 1961

Family LIMONIIDAE Speiser, 1909

Synonymy. Architipulidae Handlirsch, 1906 (synonymised by Kalugina In: Kalugina and Kovalev, 1985, p. 50); Eoasilidae Bode, 1953 (synonymised by Krzemiński and Kovalev, 1988, p. 55-56).

Subfamily ARCHITIPULINAE Handlirsch, 1906

Type genus. Architipula Handlirsch, 1906.

Genus ARCHITIPULA Handlirsch, 1906

Synonymy. Liassotipula Tillyard, 1933 (new synonymy); Eoasilidea Bode, 1953 (synonymised by Krzemiński and Kovalev, 1988, p. 55-56); Protipula Handlirsch, 1906 (synonymised by Evenhuis, 1994, p. 62); Paratipula Bode, 1953 (synonymised by Evenhuis, 1994, p. 62).

Type species. Architipula seebachiana Handlirsch, 1906 (= Architipula seebachi [Geinitz, 1884]), Toarcian (Lower Jurassic), Dobbertin in Mecklenburg, Germany.

Included species. Of the approximately 50 named species, the following, from the Lower Jurassic of Germany, can be confidently assigned to the genus Architipula: A. arculifera Bode, 1905; $A$. bodeisimilis Bode, 1953; A. formosa Bode, 1953; A. fragmentosa (Bode, 1953); A. maior Handlirsch, 1939; A. stigmatica Handlirsch,1906; and A. latipennis Handlirsch, 1906. Re-examination of the holotypes of other named species is required to establish membership of Architipula since their generic affiliation cannot be determined on the basis of existing descriptions and drawings. Architipula youngi Krzemiński from the Norian (Upper Triassic) of North America is the oldest representative of the genus (Krzemiński, 1992a).

Revised diagnosis. Vein Sc ends after fork of vein Rs into $R_{2+3+4}$ and $R_{5}$; Rs long, subequal to or a little shorter than veins $R_{2+3}$ and $R_{3}$ combined; $d$-cell characteristically deeply indented in basal part (Figures 1-2), upper part of d-cell 1.5-2x longer than its lower part (from the forking of Mb to crossvein $\mathrm{m}-\mathrm{cu}$ ); cross-vein $\mathrm{m}-\mathrm{m}$ between $\mathrm{M}_{1+2}$ and $M_{3}$ 


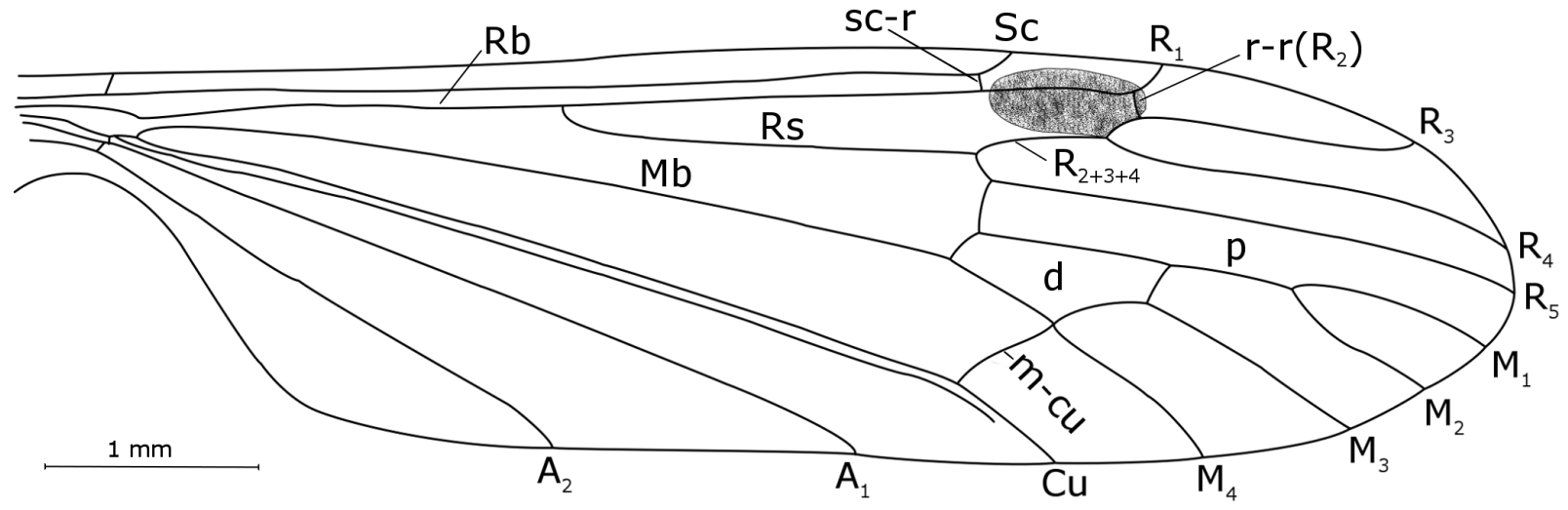

FIGURE 1. Wing venation of Architipula seebachi (Geinitz, 1884). SGWG 122/82, holotype of $A$. seebachiana Handlirsch, 1906.

distinctly inclined, its bottom part shifted towards the wing's base (unlike in most Limoniidae); vein $M_{3}$ usually distinctly sinuous; cross-vein m-cu situated close to origin of the fork of $\mathrm{M}_{3+4}$ into $\mathrm{M}_{3}$ and $\mathrm{M}_{4} ; \mathrm{A}_{2}$ usually short and straight.

\section{Architipula seebachi (Geinitz, 1884)}

Figures 1, 2

Synonymy. Phryganidium (Hydropsyche) seebachi Geinitz, 1884; Architipula seebachiana Handlirsch, 1906 (new synonymy).

Material examined. SGWG 119/6, holotype of Architipula seebachi (Geinitz, 1884) and SGWG 122/82, holotype of Architipula seebachiana Handlirsch, 1906. Both from Toarcian (Lower Jurassic) of Dobbertin (Germany) and deposited in the collection Ernst-Moritz-Arndt-Universität Greifswald.

Redescription. Vein Sc ends before mid-point of vein $R_{2+3+4}$; $R$ s long, subequal to veins $R_{2+3+4}+R_{2+3}$ and $R_{3}$ combined; $R_{4}$ three times longer than
$\mathrm{R}_{2+3+4}$; stigma large and distinct; $\mathrm{d}$-cell characteristically deeply indented in basal part, upper part of d-cell 1.5- 2 times longer than its lower part (from the forking of $\mathrm{Mb}$ to cross-vein $\mathrm{m}$-cu); d-cell about 0.14 the length of the wing; cross-vein $\mathrm{m}-\mathrm{m}$ between $M_{1+2}$ and $M_{3}$ distinctly inclined, its bottom part shifted towards the wing base; vein $\mathrm{M}_{3}$ usually distinctly sinuous; $M_{1}$ equal in length to d-cell; cross-vein m-cu situated in the fork of $M_{3+4}$ into $M_{3}$ and $\mathrm{M}_{4} ; \mathrm{A}_{2}$ usually short and straight.

Remarks. Originally considered to be the type species of the genus, Architipula seebachiana Handlirsch, 1906 is synonymous with Architipula seebachi (Geinitz, 1884), which was described as Phryganidium (Hydropsyche) seebachi Geinitz, 1884 and incorrectly assigned to the order Trichoptera, before being transferred to Architipula by Handlirsch in 1906. Both specimens came from the same Toarcian locality of Dobbertin in Germany, and their wings are almost indistinguishable in vein

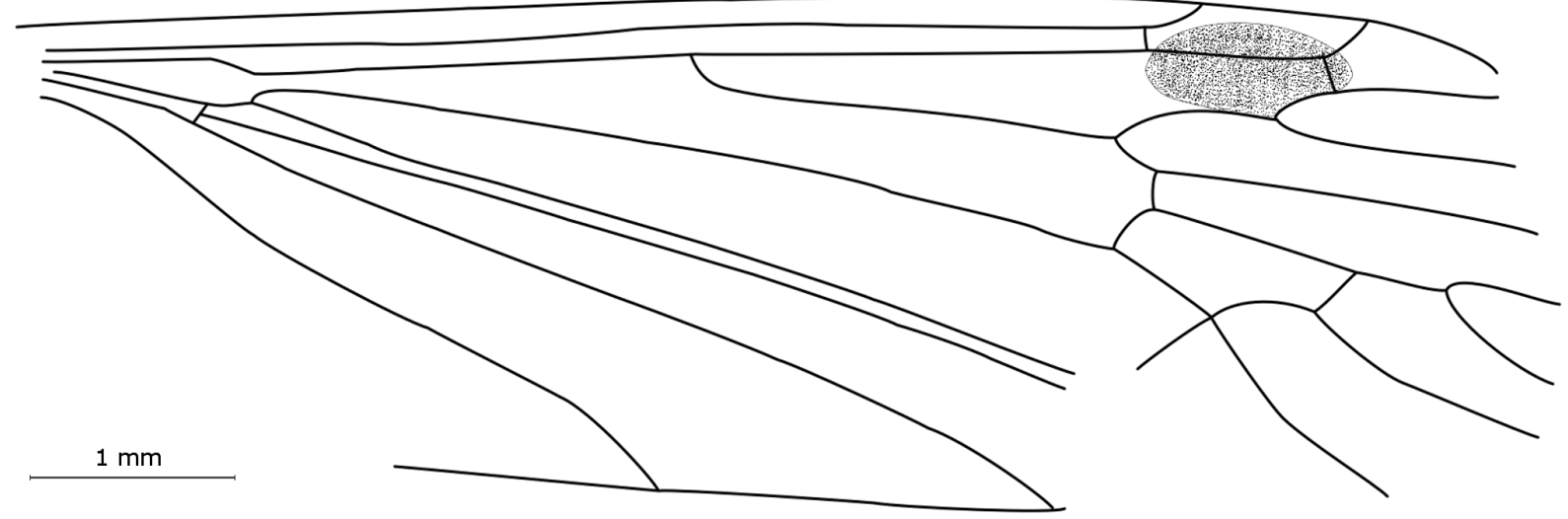

FIGURE 2. Wing venation of Architipula seebachi (Geinitz, 1884). SGWG 119/6, holotype. 
lengths and proportions. Observable morphological differences, such as the degree of curvature of $\mathrm{M}_{4}$ and the slightly longer Sc vein in $A$. seebachi, we consider to be accounted for by intraspecific variation.

Architipula anglicana (Tillyard, 1933) - comb. nov. Figure 3

Revised diagnosis. Wing 7.5-10.0 mm long; Sc ending opposite mid-length of $R_{2+3+4} ; R_{4}$ about three times as long as $R_{2+3+4}$; and slightly longer than Rs; $M_{1}$ about three times longer than petiolus; upper part of d-cell approximately twice as long as lower; $\mathrm{M}_{3}$ markedly undulate.

Redescription. Sc terminates opposite mid-length of $R_{2+3+4}$; cross-vein sc-r situated twice its length before tip of Sc; $R_{1}$ ends opposite one third length of $R_{2+3}$ and $R_{3}$ combined; $r-r\left(R_{2}\right)$ situated almost twice its length before tip of $R_{1}$; Rs very long, almost equal to $R_{4} ; R_{4} 3.5$ times as long as $R_{2+3+4}$ and slightly longer than Rs; d-cell large (about 0.17 the length of the wing), elongate along the upper edge (top of cross-vein $\mathrm{m}-\mathrm{m}$ shifted away from wing base); $\mathrm{M}_{1}$ about three times longer than petiolus and slightly longer than the d-cell; $M_{3}$ prominently undulate and almost 3.5 times longer than the basal part of d-cell; mc-u in holotype just before bifurcation of $M_{3+4}$ into $M_{3}$ and $M_{4}$, in the remaining specimens located at the fork $\mathrm{M}_{3+4} ; \mathrm{A}_{2}$ relatively long and almost straight, terminally slightly curved to wing margin.

Material examined. Holotype: In. 11298, Alderton Hill from Brodie collection. Other material: I. 11272 also from Alderton Hill; I. 11313, I. 11365, and I. 11398 from Dumbleton, Upper Lias (Lower Jurassic: Toarcian). All specimens are housed in the Natural History Museum, London.
Remarks. Examination of the holotype In. 11298 and additional specimens of Architipula anglicana allowed us to rectify mistakes in the drawing of the holotype by Tillyard (1933, p. 76), which led to his creation of a new genus; for example, in the position of cross-vein $\mathrm{m}$-cu, the addition of cross-veins in the radial sector and the length of Sc. The venation of $A$. anglicana is, in fact, very similar to that of $A$. seebachi, notably in the length of vein Sc and the construction of the d-cell, cross-vein $\mathrm{m}-\mathrm{m}$ situated between $M_{1+2}$ and $M_{3}$, strongly oblique, its upper part towards the distal part of the wing; $M_{3}$ distinctly wavy. It clearly differs in the ratio of the length of the d-cell to the length of the wing, the proportion of $M_{1}$ to its petiolus and the location of cross-vein m-cu (Figures 1-3). These differences justify separation at the species, but not genus level, and we have therefore synonymised Liassotipula with Architipula.

Genus Grimmenia Krzemiński and Zessin, 1990 stat. $\mathrm{n}$.

zoobank.org/AA932CA4-CC14-4BAA-A34F-28701224F6D8

Type species. Architipula (Grimmenia) prima Krzemiński and Zessin, 1990; Lower Jurassic (Toarcian) of Germany.

Revised diagnosis. Sc ending before or opposite the fork of Rs; cross-vein sc-r at the end of Sc; Rs long; four medial veins present; $d$ cell long and its lower part not incised like in the genus Architipula; cross-vein $\mathrm{m}$-cu in or near the fork of $\mathrm{M}_{3+4}$.

Included species. In addition to the type species and new species described below, Grimmenia secunda Krzemiński and Zessin (1990), from the Lower Jurassic (Toarcian) of Grimmen, Germany.

Grimmenia tillyardi n. sp.

Figure 4

zoobank.org/600AC2CE-0C88-445A-8E19-1C92A111F3CE

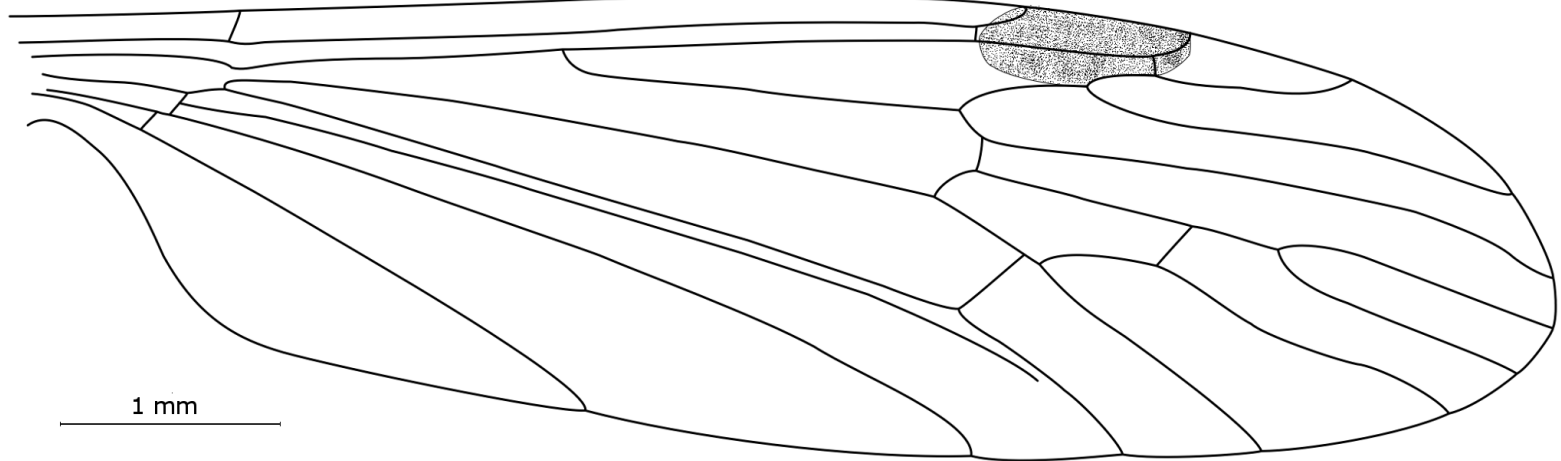

FIGURE 3. Wing venation of Architipula anglicana (Tillyard, 1933). In. 11298, holotype. 


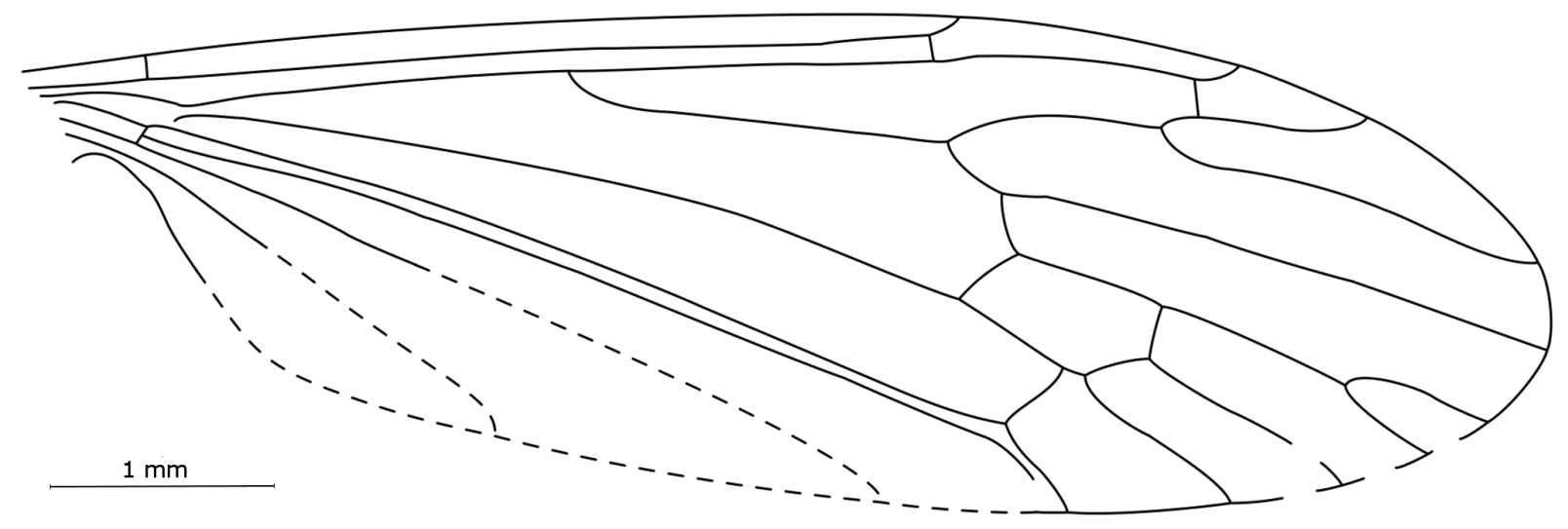

FIGURE 4. Wing venation of Grimmenia tillyardi new species. I. 3328, holotype.

Etymology. The species name is dedicated to Robin John Tillyard, the palaeoentomologist who described the first Limoniidae from the Jurassic of England.

Holotype. I. 3328 from Alderton Hill (Gloucester), Upper Lias (Lower Jurassic: Toarcian), housed in the Natural History Museum, London.

Diagnosis. Sc terminates opposite fork of Rs into $R_{2+3+4}$ and $R_{5} ; R_{2+3+4}$ long, distinctly longer than in other known species of the genus, equal to $R_{2+3}$ and $R_{3}$ combined; $R s$ almost twice as long as $\mathrm{R}_{2+3+4}$; $\mathrm{d}$-cell short and wide, which clearly differentiates this species from all congeners.

Description. Wing length $3.8 \mathrm{~mm}$; Sc ends opposite bifurcation of $R s$ into $R_{2+3+4}$ and $R_{5}$; cross-vein sc-r situated its own length before tip of Sc; $R_{1}$ ends opposite one third length of $R_{2+3}$ and $R_{3}$ combined; $R_{2+3+4}$ very long, as long as $R_{2+3}$ and $R_{3}$ combined; Rs almost twice as long as $R_{2+3+4} ; R_{4}$ equal in length to $R s$ and twice as long as $R_{2+3+4}$; $d$-cell 0.125 the length of the wing; almost rectangular, its upper part almost the same length as its basal part; top part of cross-vein $\mathrm{m}-\mathrm{m}$ inclined towards the wing base; $M_{1}$ shorter than petiolus; $m$-cu situated towards distal end of $d$-cell, just before fork of $M_{3+4}$ into $\mathrm{M}_{3}$ and $\mathrm{M}_{4}$.

Remarks. Grimmenia tillyardi $\mathrm{n}$. $\mathrm{sp}$. is very similar to G. prima from the Toarcian of Grimmen, Germany (Krzemiński and Zessin, 1990). However, it clearly differs from this species in its longer vein $R_{2+3+4}$; the shape of the d-cell, which is short and wide, and longer veins $M_{1}$ and $M_{2}$.

\section{DISCUSSION}

The limoniid fauna from the Toarcian of England has a very strong resemblance to that from Germany. In both faunas, species of the genus Architipula are the most commonly found as fossils. Handlirsch $(1906,1939)$ believed that Jurassic Diptera with wing venation similar to the family Limoniidae belonged to a separate family, Architipulidae; as did Tillyard (1933), Bode (1953) and Rohdendorf (1962). Kalugina (1985, in Kalugina and Kovalev 1985) instead included Architipulidae in the family Limoniidae as a subfamily. However, so far the subfamily has not been clearly defined, because Kalugina did not re-examine the material described by Handlirsch $(1906,1939)$ or Bode (1953). Her decision was based on the published drawings and rare material from Asia. Bode's drawings, in particular, are very inaccurate and not suitable for comparative studies.

In addition to the revision of material of Architipula and Grimmenia herein, work on clarifying the systematics of the Architipulinae is in progress. It is known that genera from other subfamilies (Limnophilinae) and families (Tipulidae and Pediciidae) have been incorrectly assigned to the subfamily. For example, Praearchitipula abnormis (Hao and Ren, 2009) has recently been transferred from Architipulinae to family Pediciidae (Gao et al., 2015a).

Continued re-examination of deposited specimens, in particular holotypes, is required, as well as collection of new material. Most of the Early Jurassic species have been described only from isolated wings. Discovery of more complete specimens would permit determination of other characters important for clarification of taxonomic relationships, such as the structure of the male genitalia and presence or absence of tibial spurs. 


\section{ACKNOWLEDGEMENTS}

We would like to thank $\mathrm{H}$. de Jong for long discussions and inspiration to write this article. Thanks also to anonymous reviewers for providing constructive comments.

\section{REFERENCES}

Blagoderov, V.A., Grimaldi, D.A., and Fraser, N.C. 2007. How time flies for flies: diverse Diptera from the Triassic of Virginia and early radiation of the order. American Museum Novitates, 3572:1-39.

Bode, A. 1953. Die Insektenfauna des Ostniedersischsischen Oberen Lias. Palaeontographica (A), 103(1-4):1-375.

Brodie, P.B. 1845. A History of the Fossil Insects of the Secondary Rocks of England. Accompanied by a Particular Account of the Strata in Which They Occur, and of the Circumstances Connected with Their Preservation. Van Voorst, London.

Evenhuis, N.L. 1994. Catalogue of the Fossil Flies of the World (Insecta: Diptera). Backhuys Publishers, Leiden.

Gao, J., Shih, Ch., Kopeć, K., Krzemiński, W., and Ren, D. 2015a. New species and revisions of Pediciidae (Diptera) from the Middle Jurassic of northeastern China and Russia. Zootaxa, 3963(2):240-249. doi:10.11646/zootaxa.3963.2.5

Gao, J., Shih, Ch., Zhao, Y., and Ren, D. 2015b. New species of Cretolimonia and Mesotipula (Diptera: Limoniidae) from the Middle Jurassic of Northeastern China. Acta Geologica Sinica (English Edition), 89(6):1789-1796.

Geinitz,F.E. 1884. Über die Fauna des Dobbertiner Lias. Zeitschrift der Deutschen Geologischen Gesellschaft, 36:566-583.

Handlirsch, A. 1906-1908. Die fossilen Insecten und die Phylogenie der rezent Formen. Engelmann, Leipzig.

Handlirsch, A. 1939. Neue Untersuchungen über die fossilen Insekten. II. Teil. Annales des Naturhistorischen Museum Wien, 49:1-240.

Hao, J.Y. and Ren, D. 2009. Two new fossil species of Limonidae (Diptera: Nematocera) from the Middle Jurassic of northeastern China. Entomological News, 120 (2):171-178. doi:10.3157/021.120.0206

Kalugina, N.S. and Kovalev, V.G. 1985. Dipteran Insects of Jurassic of Siberia. Nauka, Moscow. (In Russian)

Kalugina, N.S. 1988. Mesozoic psychodomorph and tipulomorph dipteran insects (Tanyderidae, Eoptychopteridae, Limoniidae: Diptera). In New invertebrate fossils of Mongolia (Transactions of the Joint Soviet-Mongolian Palaeontological Expedition, 33:81-88). Nauka, Moscow. (In Russian)

Krzemiński, W. 1992a. Triassic and Lower Jurassic stage of Diptera evolution. Mitteilungen der Schweizerischen Entomologischen Gesellschaft, 65:39-59.

Krzemiński, W. 1992b. The oldest Polyneura and their importance to the phylogeny of the group. Acta Zoologica Cracoviensis, 35/1:45-52.
Krzemiński, W. and Evenhuis, N.L. 2000. Review of Diptera palaeontological records, p. 535-564. In Papp, L. and Davas, B. (eds.), General and Applied Dipterology, Contributions to a Manual of Palaearctic Diptera, 1. Science Herald, Budapest.

Krzemiński, W. and Kovalev, V.G. 1988. The taxonomic status of Architipula fragmentosa (Bode) and the family Eoasilidae (Diptera) from the Lower Jurassic. Systematic Entomology, 13:55-56.

Krzemiński, W. and Krzemińska, E. 2003. Triassic Diptera: Desriptions, revisions and phylogenetic relations. Acta Zoologica Cracoviensia, 46 (suppl.- Fossil Insects):153-184.

Krzemińska E., Krzemiński W., and Dahl, Ch. 2009. Monograph of Fossil Trichoceridae (Diptera) over 180 Million Years of Evolution. Institute of Systematic and Evolution of Animals, Polish Academy of Sciences, Kraków.

Krzemiński, W. and Zessin, W. 1990. The Lower Jurassic Limoniidae from Grimmen (Diptera, Nematocera). Deutsche entomologische Zeitschrift Neue Folge, 37(1-3):39-43.

Linnaeus, C. 1758. Systema Nature Per Regna Tria Naturae, Secundum Classes, Ordines, Genera, Species, Cum Caracteribus, Differentiis Synonymi, Locis. Tomus I. Editio decima, reformata. L. Salvii, Holmiae (=Stockholm).

Lukashevich, E.D. 2009. Limoniidae (Diptera) in the Upper Jurassic of Shar Teg, Mongolia. Zoosymposia, 3:131-154.

Oberprieler, S.K., Krzemiński, W., Hinde, J., and Yeates, D.K. 2015. First crane fly from the Upper Jurassic of Australia (Diptera: Limoniidae). Zootaxa, 4021(1):178-186. doi:10.11646/zootaxa.4021.1.8

Oosterbroek, P. 2016. Catalogue of the Craneflies of the World (Insecta, Diptera, Nematocera, Tipuloidea). Available at: ccw.naturalist.nl (accessed 3 Jan 2016).

Rohdendorf, B.B. 1961. The most ancient infraorders of Diptera from the Triassic of central Asia. Journal of Palaeontology, 3:90-100. (In Russian)

Rohdendorf, B.B. 1962. ORDER DIPTERA, P. 307-345. In Rohdendorf, B. (ed.), Fundamentals of Paleontology. Arthropoda: Tracheata and Chelicerata. Nauka Press, Moscow. (In Russian).

Shcherbakov, D.E., Lukashevich, E.D., and Blagoderov, V.A. 1995. Triassic Diptera and initial radiation of the order. International Journal of Dipterological Research, 6(2):75-115.

Speiser, P. 1909 "1910". Diptera. Orthorhapha, p. 31112. In Sjöstedt, Y. (ed.), Wissenschaftliche Ergebnisse der Schwedischen Zoologischen Expedition nach dem Kilimandjaro, dem Meru und den umgebenden Massaisteppen Deutsch-Ostafrikas 19051906, unter Leitung von Prof. Dr. Yngve Sjöstedt. Herausgegeben mit Unterstützung von der Königl. Schwedischen Akademie der Wissenschaften. 2. Band, Abteilung 8-14. P. Palmquists Aktiebolag, Stockholm. 
Tillyard, R.J. 1933. The Panorpoid Complex in the British Rhaetic and Lias. Fossil Insects, 3. British Museum (Natural History), London. 